\title{
Aspergillus fumigatus and Related Species
}

\author{
Janyce A. Sugui ${ }^{1}$, Kyung J. Kwon-Chung ${ }^{1}$, Praveen R. Juvvadii ${ }^{2}$, Jean-Paul Latgé ${ }^{3}$, \\ and William J. Steinbach ${ }^{2,4}$ \\ ${ }^{1}$ Laboratory of Clinical Infectious Diseases, National Institute of Allergy and Infectious Diseases, \\ National Institutes of Health, Bethesda, Maryland 20892 \\ ${ }^{2}$ Department of Pediatrics, Division of Pediatric Infectious Diseases, Duke University, Durham, \\ North Carolina 27715 \\ ${ }^{3}$ Unité des Aspergillus, Institut Pasteur, Paris 75724, France \\ ${ }^{4}$ Department of Molecular Genetics and Microbiology, Duke University, Durham, North Carolina 27710 \\ Correspondence: bill.steinbach@duke.edu
}

\begin{abstract}
The genus Aspergillus contains etiologic agents of aspergillosis. The clinical manifestations of the disease range from allergic reaction to invasive pulmonary infection. Among the pathogenic aspergilli, Aspergillus fumigatus is most ubiquitous in the environment and is the major cause of the disease, followed by Aspergillus flavus, Aspergillus niger, Aspergillus terreus, Aspergillus nidulans, and several species in the section Fumigati that morphologically resemble $A$. fumigatus. Patients that are at risk for acquiring aspergillosis are those with an altered immune system. Early diagnosis, species identification, and adequate antifungal therapy are key elements for treatment of the disease, especially in cases of pulmonary invasive aspergillosis that often advance very rapidly. Incorporating knowledge of the basic biology of Aspergillus species to that of the diseases that they cause is fundamental for further progress in the field.
\end{abstract}

nvasive aspergillosis (IA) is one of the most serious clinical invasive fungal infections, resulting in a high case-fatality rate among immunocompromised patients (Lin et al. 2001). The disease is caused by saprophytic molds in the genus Aspergillus. Established by Micheli in 1729, the genus Aspergillus was created to accommodate an asexual fungus that produces spore chains or columns radiating from central structures. As a priest, Micheli recognized the resemblance of the spore-forming structures with that of the aspergillum (holy water sprinkler), and therefore applied the name Aspergil- lus to the fungus. More than 100 years later, Aspergillus fumigatus, the most important pathogenic species of the genus, was described by Fresenius (1863), and the role of aspergilli in human disease was first recognized by Virchow in 1856 (Virchow 1856). Virchow noticed the similarity between the aspergilli described from cases of animal infections and those he had observed in human disease. IA was later first recognized by Rankin, when he reported disseminated aspergillosis in a patient with aplastic anemia (Rankin 1953). For the subsequent 60 years, the number of cases of IA increased

Editors: Arturo Casadevall, Aaron P. Mitchell, Judith Berman, Kyung J. Kwon-Chung, John R. Perfect, and Joseph Heitman Additional Perspectives on Human Fungal Pathogens available at www.perspectivesinmedicine.org

Copyright (C) 2015 Cold Spring Harbor Laboratory Press; all rights reserved; doi: 10.1101/cshperspect.a019786 Cite this article as Cold Spring Harb Perspect Med 2015;5:a019786 
J.A. Sugui et al.

substantially because of an increase in the number of immunocompromised patients, such as those with malignancies, AIDS, solid organ transplantation (SOT), and those patients receiving immunosuppressive treatments for countless underlying conditions (Denning 1998; Kontoyiannis and Bodey 2002; Marr et al. 2002a).

\section{MYCOLOGY}

Taxonomy and Nomenclature of the Pathogenic Aspergillus Species

The genus Aspergillus is characterized by the formation of flask-shaped or cylindrical phialides either in a single or double series on the surface of a vesicle at the apex of a conidiophore (Raper and Fennell 1965). Conidia are deciduous and globose, oblong to elliptical in shape, and present various colors. In 1926, Thom and Church assembled all available information on Aspergillus in a monograph (Thom and Church 1926). In 1965, Raper and Fennell expanded this work by adding many new species and provided descriptions of the species classified into 18 informal groups (Raper and Fennell 1965). In 1985, Gams and coinvestigators revised the groups and assigned them to 18 sections as a formal taxonomic status (Gams et al. 1985). Currently, there are approximately 250 species assigned to 17 sections in the family Aspergillaceae (Houbraken and Samson 2011) and this number will continue to grow as new species are described. The major species known to cause disease in humans are found in five Aspergillus sections: Fumigati, Flavi, Nigri, Terrei, and Nidulante. The most common species causing invasive disease is A. fumigatus in the section Fumigati. Aspergillus flavus (section Flavi), Aspergillus niger (section Nigri), and Aspergillus terreus (section Terrei) are secondary to A. fumigatus as etiologic agents in SOT and hematopoietic stem cell transplantation (HSCT) recipients as well as patients with leukemia (Perfect et al. 2001; Marr et al. 2002a; Pagano et al. 2010; Pappas et al. 2010). Aspergillus nidulans (section Nidulante) rarely causes IA in immunocompromised patients, but is a common etiology of IA in patients with chronic granulomatous disease (CGD) (Cohen et al. 1981; Henriet et al. 2013). A. fumigatus, A. flavus, and A. nidulans reproduce asexually and sexually, and their sexual states have been described in the genus Neosartorya (O'Gorman et al. 2009), Petromyces (Horn et al. 2009), and Emericella (Kwon-Chung and Bennett 1992), respectively. Because the description of a sexual state merely completes the characterization of the fungus that is usually already known (Kwon-Chung and Bennett 1992), these names have been abandoned in 2013 as the fungal nomenclatural rule was changed to use only one name for one fungal species (Hawksworth et al. 2011). Sexual reproduction in heterothallic aspergilli, such as A. fumigatus and A. flavus, requires two strains of compatible opposite mating types. Sexual reproduction in homothallic species, such as A. nidulans, is accomplished by a single strain harboring the two compatible mating-type loci required for mating. In heterothallic or homothallic species, mating produces ascospores, sexual spores formed by meiosis, which are enclosed inside sexual fruiting bodies called cleistothecia. Most ascospores have a furrow or slit (Houbraken and Samson 2011).

\section{A. fumigatus and Other Pathogenic Members of Section Fumigati}

The section Fumigati is of special interest to the field of infectious diseases because this section includes not only A. fumigatus but also 11 other species as the etiologic agents of IA. Section Fumigati is characterized by the formation of a conidiophore with columnar conidial heads consisting of flask-shaped vesicles, uniseriate phialides, and long chains of conidia. Conidia are bluish-green to pale green, generally hydrophobic, and have a size of $2.5-3.5 \mu \mathrm{m}$. It has been estimated that $A$. fumigatus is the etiologic agent of various forms of aspergillosis in more than 200,000 patients a year (Brown et al. 2012). It is unclear whether this estimate represents only those caused by A. fumigatus or includes its morphologically indistinguishable sister species. Molecular diagnostic approaches have revealed that there are at least 11 species that could 
easily be confused with $A$. fumigatus based on their conidial morphology. Besides A. fumigatus, the sister species Aspergillus udagawae (Neosartorya udagawae), Aspergillus pseudofischeri (Neosartorya pseudofischeri), Aspergillus lentulus, Aspergillus felis, Aspergillus hiratsukae (Neosartorya hiratsukae), Aspergillus fischeranus (Neosartorya fischeri), Aspergillus viridinutans, Aspergillus fumisynnematus, Aspergillus fumigatiaffinis, Aspergillus novofumigatus, and Aspergillus laciniosa (Neosartorya laciniosa) have been reported sporadically in cases of aspergillosis. Of these, A. udagawae, A. lentulus, and A. pseudofischeri have been reported more frequently (Padhye et al. 1994; Alcazar-Fuoli et al. 2008; Alhambra et al. 2008; Vinh et al. 2009b; Gyotoku et al. 2012; Zbinden et al. 2012) than the other eight species (Lonial et al. 1997; Guarro et al. 2002; Yaguchi et al. 2007; Alcazar-Fuoli et al. 2008; Shivaprakash et al. 2009; Vinh et al. 2009a; Barrs et al. 2013; Malejczyk et al. 2013; Pelaez et al. 2013; Singh et al. 2013). A sexual state (Neosartorya) was described in nine of the 12 pathogenic species in the section Fumigati (Samson et al. 2007; O'Gorman et al. 2009; Swilaiman et al. 2013). It could be that the three asexual species, A. fumisynnematus, $A$. fumigatiaffinis, and $A$. novofumigatus, require nonconventional growth conditions to undergo the sexual cycle, as was the case with A. fumigatus (O'Gorman et al. 2009).

\section{ECOLOGY}

Aspergillus species from section Fumigati as well as the other four major aspergilli known to cause disease in humans (A. nidulans, A. flavus, $A$. terreus, and $A$. niger) are found in a wide variety of substrata, including soil, compost piles, fruits, organic debris, animals, and humans (Thom and Church 1918; Samson et al. 2007; Barrs et al. 2013). Although most of these species are ubiquitous in the environment (Raper and Fennell 1965), A. fumigatus remains the major cause of IA. One reason for the prevalence of A. fumigatus as the main clinical cause of aspergillosis is the exceedingly high abundance of the species, with the average human inhaling hundreds of airborne conidia daily
(Latgé 1999). A. fumigatus is more ubiquitous than other aspergilli owing to their superior ability to survive and grow in a wider range of environmental conditions compared to other species. In the saprophytic cycle, conidia released from conidiophores are readily dispersed in the environment. Conidia remain dormant until encountering the environmental conditions that allow activation of their metabolism. Once metabolically active, conidia swell and germinate into hyphal filaments that grow into mycelium and produce conidia bearing fruiting structures (conidiophores) (Fig. 1).

Although A. fumigatus grows optimally at $37^{\circ} \mathrm{C}$, it can be isolated wherever soil and decaying vegetation reach temperatures ranging between $12^{\circ} \mathrm{C}$ and $65^{\circ} \mathrm{C}$, as well as $\mathrm{pH}$ between 2.1 and 8.8 (Jensen 1931). Owing to its pronounced ability to tolerate high temperature, self-heating compost piles are major environmental sources (Latgé 1999; Kwon-Chung and Sugui 2013). A. fumigatus also contains numerous genes encoding glycosylhydrolases and extracellular proteinases in its genome, whose products support the ability to grow successfully by degrading polysaccharides from plant cells and acquiring nitrogen by degradation of proteinacious substrates (Tekaia and Latgé 2005; Abad et al. 2010). Not only can A. fumigatus grow on a wide variety of substrates, but it can also tolerate stresses imposed by freezing or dehydration for prolonged periods (Kozakiewicz and Smith 1994). Furthermore, conidia of A. fumigatus disperse more readily than most other aspergilli because of the notorious hydrophobicity of A. fumigatus conidia (Bayry et al. 2012). The ubiquitous nature of A. fumigatus is also partly because of its ability to produce potent secondary metabolites and abundant efflux pumps that serve as defense systems (Kwon-Chung and Sugui 2013).

\section{LABORATORY IDENTIFICATION AND BIOLOGY}

Identification of the Aspergillus species is based on a combination of biotype and genotype. A biotype involves cultural and morphological characteristics, whereas a genotype is defined 
J.A. Sugui et al.

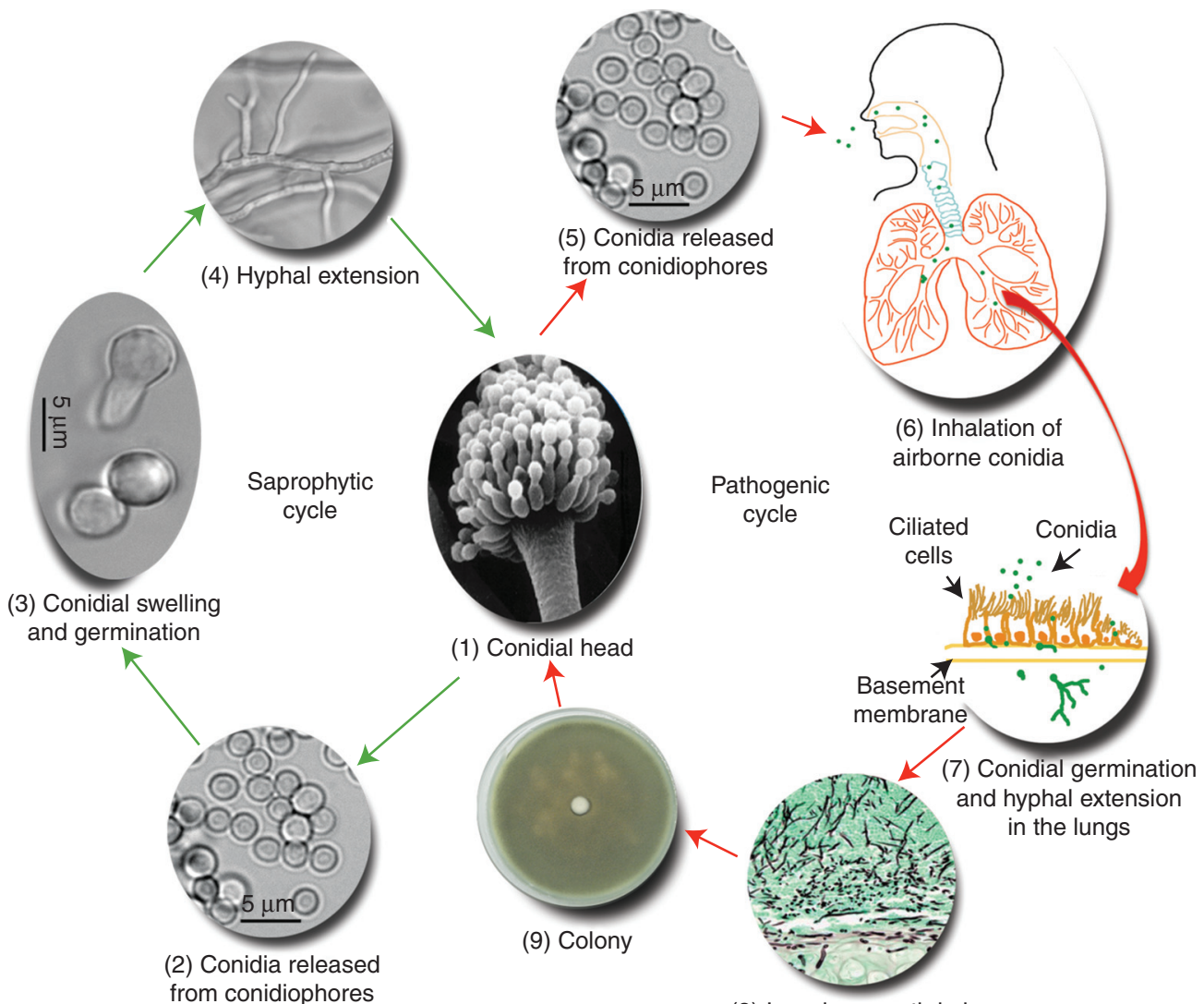

(8) Invasive growth in lungs

Figure 1. Saprophytic and pathogenic cycles of A. fumigatus. Saprophytic cycle: (1) A. fumigatus conidial head bearing conidia (spores). (2) Mature conidia are highly hydrophobic and readily dispersed. (3) On germination, conidia swell and germinate into hyphal filaments. (4) Extension of hyphal filaments forms an interwoven net called mycelia. Pathogenic cycle: (5) and (6) Airborne conidia are constantly inhaled by humans. (7) In severely immunosuppressed patients, conidia may escape from host defenses and grow invasively. (8) Extensive hyphal growth in the lungs of an immunocompromised patient. (9) Colony growth.

by the sequences of certain genes. Etiologic agents of aspergillosis are typically very distinct in their appearance; thus the biotype (shape, size, and color of the conidial head, thermotolerance, etc.) is a good indicator of their identity. For example, the bluish-green color of A. fumigatus conidial heads is clearly distinct from the yellowish-green, tan, dark green, or black conidial heads of A. flavus, A. terreus, A. nidulans, and A. niger, respectively (Fig. 2). In instances in which differences in the color of conidial heads are not clear, other characteristics can be helpful in species identification. For example, $A$. nidulans possesses deep green conidial heads, which might be mistaken for the bluish-green color from A. fumigatus (Fig. 2). Unlike A. fumigatus, however, $A$. nidulans conidia are produced by biseriate phialides. The presence of Hülle cells enclosing the cleistothecia produced by $\mathrm{A}$. nidulans can also serve as a differential marker. Hülle cells are thick-walled, variously shaped, cells that often encase cleistothecia (Raper and Fennell 1965; Kwon-Chung and Bennett 1992). Conidial size can also aid in the identification of some species. A. fumigatus, A. terreus, and A. nidulans all have conidia ranging from 2 to $3.5 \mu \mathrm{m}$, whereas conidia from A. flavus and A. niger are larger $(3-5 \mu \mathrm{m})$ (Raper and Fennell 


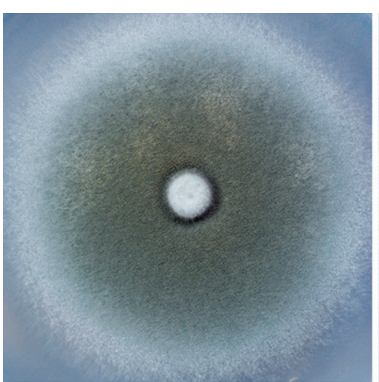

Aspergillus fumigatus

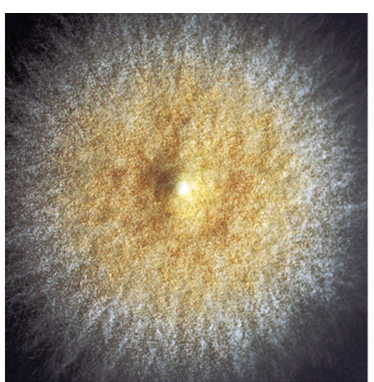

Aspergillus terreus

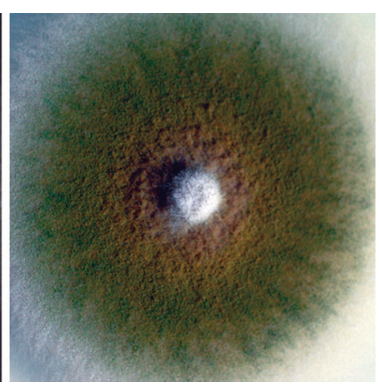

Aspergillus nidulans

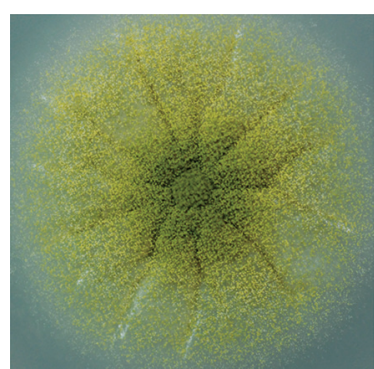

Aspergillus flavus

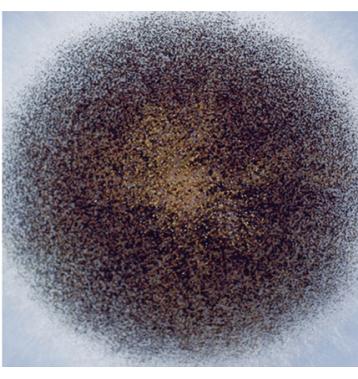

Aspergillus niger

Figure 2. Major pathogenic species of Aspergillus. A. fumigatus, A. terreus, A. nidulans, A. flavus, and A. niger were inoculated on Czapek-Dox agar and grown at $37^{\circ} \mathrm{C}$.

1965). Although differences in biotype can often be sufficient to distinguish A. fumigatus from other aspergilli, identification should be confirmed by their genotype. Internal transcribed spacer (ITS) sequences, along with others such as fungal sequences from the genes $M C M 7$, TSR1, RPB1, and RPB2, are useful for species identification (White et al. 1990; Peterson 2008; Schmitt et al. 2009).

Although differentiation between A. fumigatus and the pathogenic species from other sections of Aspergillus is relatively straightforward because of their distinct morphology, differentiation between A. fumigatus and its sister species becomes difficult because of their morphological resemblance. In fact, relying solely on morphological characteristics has led to misidentification of several of the sister species. One of the first clues suggesting misidentification of the sister species was the extensive aerial hyphal growth with delayed and sparser conidiation on agar compared to the fast and abundant production of conida in A. fumigatus. Thermotolerance is another key biotype that can aid in the differentiation of $A$. fumigatus from its sister species. Whereas A. fumigatus is able to grow at $50^{\circ} \mathrm{C}$ but not at $10^{\circ} \mathrm{C}$, the sister species are generally able to grow at $10^{\circ} \mathrm{C}$ but not at $50^{\circ} \mathrm{C}$ (Samson et al. 2007; Sugui et al. 2010; Posteraro et al. 2011; Barrs et al. 2013). Compared to biotype analysis, which requires a few days to weeks before the characteristic fruiting structures are produced, genotype analysis can be performed as soon as the species grows efficiently to allow DNA isolation. The ITS sequence is reliable in determining the Aspergillus sections, but lacks variability in species identification within the section Fumigati. Alternatively, the sequences from the genes encoding $\beta$-tubulin, rodlet $A$, and calmodulin are more suitable for the distinction between A. fumigatus and its sister species (Samson et al. 2007). A minimum of $99 \%$ sequence identity is the typical threshold adopted for species determination in Aspergillus.

Aspergillus species differentiation can be clinically important for antifungal treatment selection. Two studies analyzing the minimal in- 
J.A. Sugui et al.

hibitory concentration (MIC) distribution of more than 5000 isolates, including A. fumigatus, A. flavus, A. niger, A. terreus, and A. nidulans, showed that some species are significantly more susceptible to amphotericin B, itraconazole, or voriconazole (Espinel-Ingroff et al. 2010, 2011). In the case of $A$. pseudofischeri and A. udagawae in the section Fumigati, susceptibility to amphotericin B and itraconazole is somewhat controversial. For voriconazole, on the other hand, there is a general consensus that these species are less susceptible than A. fumigatus (Balajee et al. 2006; Vinh et al. 2009b; Posteraro et al. 2011). The variable susceptibility to antifungals may have contributed to the different outcomes observed in patients; although treatment with antifungals was effective in several cases with $A$. pseudofischeri and A. udagawae, fungal growth was uncontrolled in other cases despite antifungal treatment (Coriglione et al. 1990; Summerbell et al. 1992; Jarv et al. 2004; Ghebremedhin et al. 2009; Vinh et al. 2009b; Posteraro et al. 2011; Gyotoku et al. 2012; Toskova et al. 2013). A. lentulus is overall less susceptible than A. fumigatus to amphotericin B, itraconazole, and voriconazole based on its high MICs (Balajee et al. 2006; Alcazar-Fuoli et al. 2008; Symoens et al. 2010). These in vitro susceptibilities correlate, to some extent, with the findings in clinical settings. Death of a significant number of patients infected by A. lentulus, despite treatment with antifungals, substantiates that $A$. lentulus is more refractory to antifungal agents than A. fumigatus (Alhambra et al. 2008; Montenegro et al. 2009; Zbinden et al. 2012).

\section{PATHOGENESIS}

One of the most relevant questions in understanding the pathobiology of A. fumigatus is identifying virulence determinants. This is complicated because of the redundancy of genes with the same functions, pleiotropic effects of several genes, and complex enzymatic systems encoded by gene clusters. Moreover, as a successful saprophyte, A. fumigatus does not possess any particular set of virulence factors. According to the classical definition of "virulence factors," which includes genes that affect virulence but are dispensable for normal growth, only a few genes/ molecules fulfill these requirements. Two of these factors are conidial melanin and gliotoxin. A. fumigatus does not require either of these two factors for growth; however, loss of conidial melanin rendered $A$. fumigatus nearly avirulent when inoculated intravenously in BALB/c mice (Tsai et al. 1998) and, in the absence of gliotoxin synthesis, virulence was reduced in a host immune-status dependent manner. Reduced virulence was observed in non-neutropenic mice immunosuppressed with hydrocortisone (Sugui et al. 2007; Spikes et al. 2008) but not in neutropenic mice immunosuppressed with cyclophosphamide and cortisone (Cramer et al. 2006; Kupfahl et al. 2006). Melanin and gliotoxin are part of the fungal defense system to survive in an extreme environment, such as in soil in which thousands of microorganisms cohabit. To a certain degree, such a defense system may also protect aspergilli in the host environment (Kwon-Chung and Sugui 2013).

As an opportunistic pathogen, nearly all published A. fumigatus mutant strains defective in genes responsible for its normal growth through proper hyphal extension exhibit a virulence defect in murine models. However, it is clear that not every A. fumigatus mutant strain with an in vitro growth defect displays a virulence defect. Similar to in vitro growth, lung fungal burden has been repeatedly directly correlated to virulence in the murine model of IA. Several of these genes can be considered as virulence factors because they are crucial for fungal establishment within nutrient-limited host tissue. For instance, iron and zinc are of prime importance for A. fumigatus growth. Consequently, genes encoding proteins involved in acquisition of these two metals are indispensable for A. fumigatus to cause disease (Moreno et al. 2007; Haas 2012; Moore 2013). The calcineurin signaling pathway is another example of a system that is required for normal growth and that deeply impacts virulence of A. fumigatus (Steinbach et al. 2007). Deletion of the cnaA gene encoding the catalytic subunit calcineurin A affects the extension process of hyphal filaments. Without the ability to extend, hyphal 
invasion of the host tissue and virulence is compromised; thus, even if the fungus is able to withstand host defenses it will not cause IA. In fact, virulence of a cnaA deletion mutant in a murine model was greatly reduced compared to the wild-type strain (Steinbach et al. 2006; da Silva Ferreira et al. 2007). In general, the array of genes and molecules associated with A. fumigatus virulence can be classified based on their involvement in specific biological processes. Thermotolerance, cell-wall composition and maintenance, defense against host immune response, toxin production, and nutrient uptake during host invasion are just some examples of the processes involved (Fig. 3). The importance and the role of genes involved in these processes in A. fumigatus pathogenesis have been extensively reviewed (Hohl and Feldmesser 2007; Askew 2008; Abad et al. 2010; Sales-Campos et al. 2013).
The epithelium is the first point of contact for fungal conidia within the lung and represents an important surface of interaction. Despite this, the interactions between epithelial cells and A. fumigatus remain poorly understood (Svirshchevskaya et al. 2012). It has been reported that epithelial cell lines, such as A549, are able to internalize conidia readily, whereas primary cell lines are not. A major innate immune response to inhaled conidia is the synthesis of proinflammatory cytokines, such as IL-8, Granulocyte macrophage colony-stimulating factor, and the proapoptotic factor tumor necrosis factor- $\alpha$. Inhibition of apoptosis, which has been regarded as a mechanism by which a pathogen overcomes host defense, has been shown to be specifically induced by conidia. In addition, conidia are in contact with many different fungicidal factors present in the upper layer of the mucous epithelium. Among them,
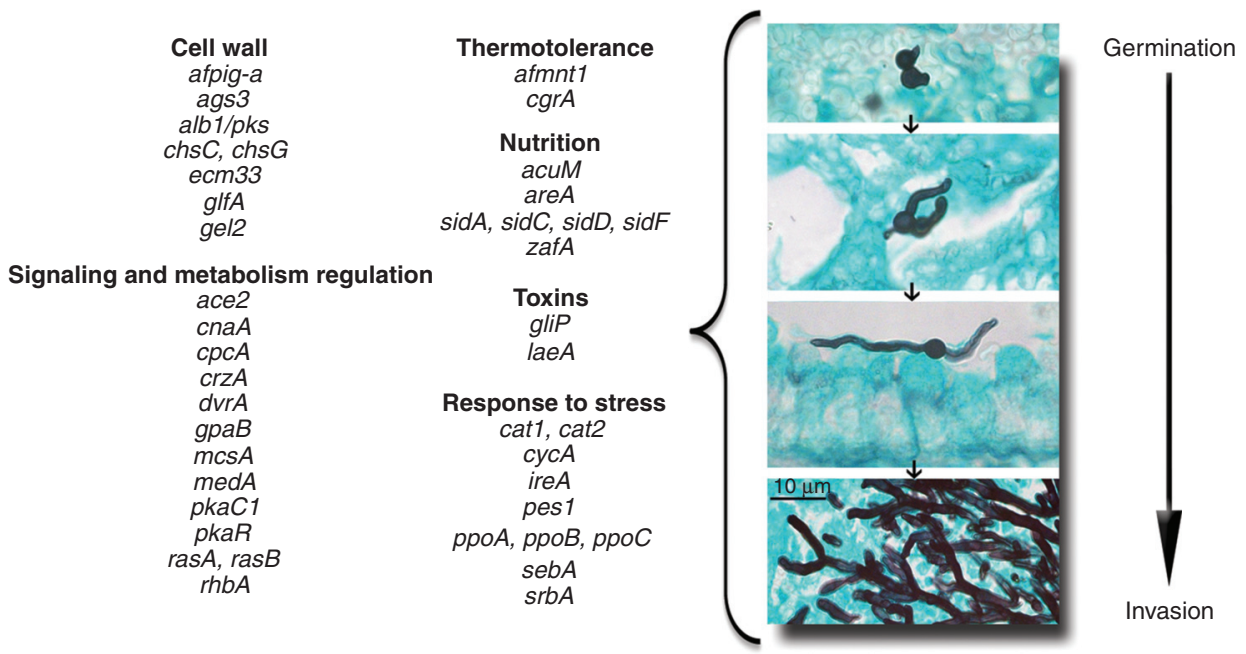

Figure 3. Select genes associated with A. fumigatus virulence. The listed genes interfere with various aspects of A. fumigatus survival, growth, and response to host defenses. Growth stages of A. fumigatus inside of lungs of mice immunosuppressed with hydrocortisone are represented. Fungal cells were stained with Grocott's methenamine silver stain. This list includes: genes controlling the cell wall (Mellado et al. 1996; Langfelder et al. 1998; Tsai et al. 1998; Mouyna et al. 2005; Maubon et al. 2006; Romano et al. 2006; Li et al. 2007; Schmalhorst et al. 2008), signaling and metabolism regulation (Panepinto et al. 2003; Krappmann et al. 2004; Liebmann et al. 2004; Fortwendel et al. 2005, 2012; Steinbach et al. 2006; Zhao et al. 2006; da Silva Ferreira et al. 2007; Cramer et al. 2008; Ibrahim-Granet et al. 2008; Soriani et al. 2008; Ejzykowicz et al. 2009, 2010; Gravelat et al. 2010), thermotolerance (Bhabhra et al. 2004; Wagener et al. 2008), nutrition (Hensel et al. 1998; Schrettl et al. 2004, 2007; Hissen et al. 2005; Moreno et al. 2007; Liu et al. 2010), toxin genes (Bok et al. 2005; Sugui et al. 2007; Spikes et al. 2008), and response to stress (Paris et al. 2003; Tsitsigiannis et al. 2005; Reeves et al. 2006; Willger et al. 2008; Feng et al. 2011; Dinamarco et al. 2012; Grahl et al. 2012). 
J.A. Sugui et al.

the most active factors are the surfactant proteins SPA and SPD, the pentraxin-3-ficolin complexes, and the $\beta$-defensins (Okamoto et al. 2004; Alekseeva et al. 2009; Madan et al. 2010; Ma et al. 2013).

After A. fumigatus conidia bypass mucocilliary clearance and epithelial defenses, they reach the lower airways (Cohen et al. 2011). Conidia that reach the alveoli are unable to withstand the immune assault mounted by normal hosts and are effectively removed by innate immune cells (Tekaia and Latgé 2005). When they reach the alveoli, conidia are phagocytosed by alveolar macrophages. Although these conidia present several antigens and allergens, it remained an enigma as to why airborne conidia do not continuously activate host innate immune cells and induce detrimental inflammatory responses following their inhalation. This mystery was solved when it was shown that the hydrophobin layer organized in a rodlet configuration on the surface of the dormant conidia imparts immunological inertness. This was shown using conidia that were lacking the rodlet protein (RodAp) after it had been removed biologically (germ tube), chemically (hydrofluoric acid treatment, $\mathrm{HF}$ ), or genetically (rodA mutant) (Aimanianda et al. 2009). For example, in contrast to wildtype conidia, and despite being dormant, conidia of the $\Delta \operatorname{rodA}$ mutant and HF-treated conidia that lack RodAp but have exposed immunogenic determinants induced significant up-regulation of cytokines as well as costimulatory and antigen presenting molecules on human dendritic cells. The immunosilencing role of the surface hydrophobins is not only seen in A. fumigatus but is a common feature of all aerial airborne molds. Considering the fact that dormant conidia are ubiquitous in the atmosphere, the inert nature of the hydrophobin rodlet layer makes teleological sense, as it prevents undue and exacerbated host response by innate immune cells, and hence avoids inflammation and host damage (Aimanianda et al. 2009). Once internalized by macrophages, microbes are usually killed by reactive oxygen species (ROS). In the case of $A$. fumigatus, resting conidia are extremely resistant to ROS. Although this resistance is also caused by the presence of hydrophobins, the most important defense mechanisms against ROS are the underlying layer of melanin (Heinekamp et al. 2013) that scavenges host ROS in a more efficient way than the classical catalases and superoxide dismutases, as well as the many antioxidant proteins controlled by the transcriptional regulator Yap1 (Lessing et al. 2007).

After phagocytosis, conidia germinate inside the phagolysosome (Ibrahim-Granet et al. 2003) and shed their rodlet layer that is then degraded in the phagolysosome. The release of the rodlets results in the exposure of polysaccharides and immunogenic proteins that initiate a proinflammatory response. In addition, the melanin layer ruptures because of the internal osmotic pressure resulting from conidial swelling. Both events facilitate contact of host cells with the fungal PAMPs and increase cell-wall permeability to phagocyte toxic molecules. Another major consequence of this germination process is the recruitment of the neutrophils to the site of infection. Like alveolar macrophages, neutrophils are professional phagocytes whose function is essential to kill inhaled conidia as well as germinating conidia. Killing is caused by two different mechanisms: In the case of conidia, it is an intracellular killing with granules fusing to the phagolysosome; in the case of hyphae, neutrophils are able to secrete antifungal compounds from their arsenal of toxic molecules present in granules. However, with the exception of the ROS, the nature of the molecules responsible for the killing remains unknown to date. A recent discovery associated with the clustering of the neutrophils with hyphae and other immune cells has been the discovery of neutrophil extracellular traps (NETs) consisting of nuclear DNA decorated with antifungal proteins (Urban et al. 2006). However, the efficacy of hyphal killing by this extracellular mechanism remains controversial (Bruns et al. 2010; McCormick et al. 2010).

In the absence of sufficient pulmonary defenses, because of either immunosuppression that renders the human host neutropenic or cortisone injection to fight graft versus host disease that results in deficient phagocytic defense, conidia establish themselves in the lung and 
adapt their physiology to overcome the stress imposed by the host environment. Because the optimum temperature for conidial germination and growth is between $37^{\circ} \mathrm{C}$ and $45^{\circ} \mathrm{C}$, they germinate readily into hyphae by $6-8 \mathrm{~h}$ in mammalian tissue (McDonagh et al. 2008). During this early stage of germination, A. fumigatus utilizes a highly coordinated gene expression program that allows adaptation to nutrient deprivation, iron limitation, hypoxia, and other unfavorable growth conditions in the host environment (McDonagh et al. 2008). Excessive hyphal growth and dissemination follow in the profoundly neutropenic host, leading to increased risk of IA resulting in thrombosis and hemorrhage (Fig. 1) (Hohl and Feldmesser 2007; Dagenais and Keller 2009).

\section{CLINICAL PRESENTATIONS}

Aspergillus species are relatively unique among pathogens as they are responsible for a gamut of infections extending across the clinical spectrum to include primary allergic reactions, saprophytic involvement, and invasive disease. The type of Aspergillus infection generally depends on the immunologic background of the infected host, with immunodeficient patients developing invasive disease, whereas immunoreactive patients develop allergic disease. The most frequently encountered clinical presentations involve the lungs, such as acute or chronic IA and allergic bronchopulmonary aspergillosis (ABPA). Other common infections caused by Aspergillus include acute invasive or chronic sinusitis, cutaneous aspergillosis, aspergilloma, and cerebral aspergillosis. In some immunocompetent patients, inhalation of conidia could result in nonpathogenic saprophytic colonization; however, in the immunocompromised patient this conidial acquisition will likely result in establishment of invasive disease (Tomee and van der Werf 2001). The large burden of Aspergillus infections is sustained by immunocompromised individuals, including those who have undergone HSCT, SOT, cancer patients, patients with various congenital immune deficiencies such as CGD, and patients treated for autoimmune diseases (Richardson 2005).
Although cancer patients undergoing treatment constitute the a majority of patients at risk for Aspergillus infections, patients with CGD have an estimated 33\% lifetime risk of IA, and IA may in fact be the first manifestation of CGD. Although disease in a majority of patient groups is caused by either A. fumigatus or A. flavus, most cases of $A$. nidulans infection have been reported in patients with CGD (Cohen et al. 1981; Henriet et al. 2013). In addition to differences in the epidemiology of specific Aspergillus isolates, the clinical presentation in patients with CGD is characterized by an insidious onset of fatigue, fever, increased sedimentation rate, and pneumonia (Segal et al. 1998). In early disease, there is an acute neutrophilic response in which the neutrophils surround hyphae. However, in patients with CGD, the hyphae remain intact owing to impaired neutrophil-mediated killing of hyphae.

Fungal sinusitis can manifest as allergic, saprophytic, or invasive disease. Invasive Aspergillus sinusitis is likely underdiagnosed because of its variable clinical presentation and difficulty in establishing the diagnosis (Denning 1998; Ho and Yuen 2000; Marr et al. 2002b), possibly owing to a decreased inflammatory response in affected patients.

Aspergillus infections most commonly involve the lungs, but disease can disseminate via the bloodstream and involve distant organs. One of the most frequent sites of dissemination is the central nervous system (CNS) (Groll et al. 1996). There are studies that have estimated that CNS aspergillosis may be found in $40 \%-50 \%$ of patients with IA and acute leukemia or allogeneic stem cell transplant (Saugier-Veber et al. 1993; Jantunen et al. 2000).

Chronic aspergillosis is less frequently encountered than acute disease and the patient population affected is typically distinct as well. A degree of immune suppression does exist in these patients and exposure to corticosteroids is common. Underlying conditions include corticosteroid use for chronic lung disease, diabetes mellitus, and alcoholism (Denning 1998).

ABPA occurs in asthmatic and cystic fibrosis patients and is a pulmonary disease caused by types I and III hypersensitivity reactions to 
J.A. Sugui et al.

A. fumigatus allergens. Exposure and inhalation of Aspergillus conidia result in saprophytic (noninvasive) colonization of the bronchial airways, which then triggers an IgE-mediated allergic inflammatory response. Over time, bronchial obstruction develops and patients can present with productive cough, wheezing, and chest pain; fever and malaise are also presenting symptoms (Stevens et al. 2003). Treatment depends on relieving inflammation via an extended course of systemic corticosteroids and antifungal agents to decrease the fungal burden and diminish the inciting stimulus for inflammation (Stevens et al. 2000; Caputo 2003; Conway et al. 2004).

\section{EPIDEMIOLOGY}

IA was the most common mold infection in a review of approximately 5500 patients who underwent HSCT; although $>7 \%$ of HSCT recipients had mold infections, Aspergillus infections were the most common, followed by Fusarium, Mucorales, and Scedosporium infections (Marr et al. 2002a). A large prospective French study analyzed 424 cases of IA and found an incidence of $0.9 \%$ in autologous and $8.1 \%$ in allogeneic HSCT patients, respectively (Lortholary et al. 2011), highlighting a consistent finding that IA occurs much more readily in the allogeneic HSCT recipient. Among SOT recipients, the highest incidence of IA was for heart transplant recipients $(4.8 \%)$, followed by lung $(4.1 \%)$, and significantly dropping for liver $(0.8 \%)$ and kidney $(0.3 \%)$, findings that have also continued throughout most other larger studies.

The Transplant Associated Infection Surveillance Network (TRANSNET) study evaluated HSCT and SOT recipients from 23 U.S. medical centers (2001-2005) and included evaluation of a total of 642 cases of IA (Baddley et al. 2010). The 12-month cumulative incidence of IA in all HSCT recipients was $1.6 \%$, compared to $0.63 \%$ in SOT recipients. The 12 -week allcause mortality was $57.5 \%$ among HSCT recipients and $34.4 \%$ among SOT recipients.

There is a well-characterized bimodal distribution of aspergillosis in HSCT recipients that correlates with pre-engraftment neutrope- nia (median of $16 \mathrm{~d}$ after transplantation) and the peak of graft-versus-host disease (GVHD) (median of $96 \mathrm{~d}$ after transplantation) (Wald et al. 1997). This likely relates to the two major mechanisms of protection against IA: alveolar macrophages and granulocytes. Most patients (86\%) with autologous transplants were diagnosed with IA while neutropenic, whereas patients with allogeneic transplants were at greatest risk after engraftment or during impairment of cell-mediated immunity attributable to cytomegalovirus or GVHD (Wald et al. 1997).

\section{DIAGNOSTIC STRATEGIES}

The diagnosis of IA is often not straightforward. The "gold standard" of tissue biopsy is often considered too invasive and complicated by bleeding in high-risk patients. Aspergillosis diagnosed by blood culture is rare (Girmenia et al. 2001). In general, the Aspergillus hyphal mass that develops in the lumen during angioinvasion remains in place until the force of blood flow causes hyphal breakage, which then allows the mass to circulate. The likelihood of a blood culture capturing these irregularly and infrequently discharged units is small. The difficulty in detecting A. fumigatus in blood culture stands in contrast to other angioinvasive filamentous fungi (e.g., Fusarium species, Paecilomyces lilacinus, Scedosporium prolificans, Acremonium species) that have the ability to discharge a steady series of unicellular conidia into the bloodstream that are more likely to be captured in a blood sample. This ability to sporulate in tissue and blood has been termed adventitious sporulation (Schell 1995). As A. terreus also displays adventitious sporulation, histopathologic examination of these spores can allow rapid, presumptive identification of $A$. terreus. Therefore, a positive blood culture with $A$. terreus or another mold that shows adventitious sporulation should not be ignored, whereas a positive blood culture with other Aspergillus species should be further evaluated.

Serological testing for antibodies to Aspergillus antigens is helpful to diagnose aspergilloma or allergic bronchopulmonary aspergillosis in immunocompetent individuals, but 
unfortunately serology plays little role for diagnosis in the immunocompromised patient because Aspergillus growth does not correlate with an increase in anti-Aspergillus antibody titers (Latgé 1999).

Galactomannan (GM) is a major cell-wall component of Aspergillus and it is known that the highest concentrations of GM are released in the terminal phases of the disease (Latgé 1999). An enzyme-linked immunosorbent assay (ELISA) technique was introduced using a rat anti-GM monoclonal antibody, EB-A2, which recognizes the $1 \rightarrow 5$ - $\beta$-D-galactofuranoside sidechains of the GM molecule (Maertens et al. 1999). A sandwich ELISA technique was introduced in 1995 (Stynen et al. 1995), and by using the same antibody as both a capture and detector antibody in the sandwich ELISA (Platelia Aspergillus, Bio-Rad, France), the threshold for detection can be lowered to $1 \mathrm{ng} / \mathrm{ml}$. This technique is used in the current commercially available GM assay for diagnosis of IA. In a meta-analysis conducted to characterize the clinical utility of GM assay, 27 studies were identified and overall the GM assay had a sensitivity of $71 \%$ and a specificity of $89 \%$ for proven cases of IA as defined by the specific clinical criteria (Pfeiffer et al. 2006). In patients with hematologic malignancy or who have undergone HSCT, the assay was most useful but in SOT recipients, the sensitivity and specificity were $22 \%$ and $84 \%$, respectively. Serial testing at least twice a week is recommended (Denning et al. 1997). Unfortunately, the galactomannan assay has decreased sensitivity in the setting of a patient receiving anti-Aspergillus (mold-active) antifungals, although the specificity for detection does not change (Marr et al. 2004). Although GM has been extensively validated in patients with hematologic malignancy and those who have undergone HSCT, for unclear reasons, GM appears less useful in SOT recipients. False-positive results with GM can hamper its clinical utility and are seen in patients concurrently receiving some $\beta$-lactam antibacterials such as piperacillin-tazobactam, amoxicillin, and amoxicillin-clavulanate.

$(1,3)-\beta$-D-glucan is an integral cell-wall component and, in contrast to GM, is not nor- mally released from the fungal cell (Latgé 1999). Factor G, a coagulation factor of the horseshoe crab, is a highly sensitive natural detector of $(1,3)-\beta$-D-glucan (Obayashi et al. 1995). The "G test," which detects $(1,3)-\beta$-D-glucan via a modified limulus endotoxin assay, is useful for detection of fungi such as Aspergillus, Candida, and even Cryptococcus; however, it does not identify the genus of the fungi (Obayashi et al. 1995). A meta-analysis of cohort studies of $(1,3)-\beta$-D-glucan for IA revealed that using a single test resulted in a pooled sensitivity of $57 \%$ with a specificity of $97 \%$ (Lamoth et al. 2012). A study comparing galactomannan, polymerase chain reaction, and $(1,3)-\beta$-D-glucan on patients with hematological disorders and the receiver-operating characteristic (ROC) analysis showed an area under the ROC curve that was greatest for the galactomannan assay, using two consecutive positive results. This suggests that the galactomannan was the most sensitive at predicting the diagnosis of IA in highrisk patients with hematological disorders (Kawazu et al. 2004).

\section{TREATMENT}

Overall success in treating IA is dependent on numerous factors, not simply the choice of a specific antifungal therapy. As with all immunocompromised patients, detailed knowledge of host factors, underlying disease, concomitant infections, and degree and duration of immunosuppression are keys to overall treatment. It is well known that immune reconstitution is paramount to successful IA therapy, whereas continued exposure to certain immunosuppressive medications, such as corticosteroids, worsens IA. Any antifungal prophylaxis used before the diagnosis of IA could also have an effect on the ultimate choice of targeted therapy. Although the diagnostic work-up needs to be aggressive, it should never delay antifungal therapy in the setting of true concern for IA. As such, the cornerstone of antifungal therapy for IA is prompt and aggressive institution of antifungal therapy, based not only on diagnostic tools but also on clinical suspicion of infection. Antifungal resistance is slowly and steadily increasing among 
J.A. Sugui et al.

Aspergillus isolates and continues to have specific geographic trends that could influence antifungal choice. There is also the question of using antifungal monotherapy or combination antifungal therapy, and, if so, which classes of agents. Finally, although immune reconstitution is paramount, the role and real benefit of adjunctive immunotherapy remains somewhat unclear.

Voriconazole is the preferred antifungal agent for the primary therapy of IA. The global clinical trial that led to its approval was a prospective comparative study showing that voriconazole had a superior response rate in the primary treatment of IA compared to amphotericin B, $52.8 \%$ versus $31.6 \%$, respectively (Herbrecht et al. 2002). These and other studies led to the very clear guideline recommendations of the Infectious Diseases Society of America to use voriconazole for the primary treatment of IA (Walsh et al. 2008) in all clinical sites. Although voriconazole is the guideline-recommended first line agent for primary therapy of IA, it is not completely clear when the alternative agents, such as amphotericin B lipid formulations or echinocandins or the other triazoles ( posaconazole or itraconazole), should be used in place of voriconazole. The most common reason for using an alternative agent is refractory disease following primary antifungal therapy and the need to transition to salvage therapy.

\section{CONCLUSION}

The clinical diseases caused by Aspergillus species are diverse and often dependent on host immune status. Although there are hundreds of recognized Aspergillus species, it was originally thought that only a handful caused human disease. However, the breadth of infecting species is increasing as more and more sibling species are identified. Accurate identification is not only an interesting taxonomic phenomenon, but clinically relevant as many of these newly characterized species have unique and potentially dire antifungal susceptibility patterns. The Aspergillus field is rapidly advancing on all fronts, including basic biology and laboratory identification, fundamental pathogene- sis, and fungal-host interactions, as well as diagnostic and therapeutic challenges for improved clinical outcome. This bodes well for future advances to impact patient care and survival.

\section{ACKNOWLEDGMENTS}

J.A.S. and K.J.K.-C. are supported by the Intramural Research Program of the National Institute of Allergy and Infectious Diseases, National Institutes of Health, Bethesda, MD.

\section{REFERENCES}

Abad A, Fernandez-Molina JV, Bikandi J, Ramirez A, Margareto J, Sendino J, Hernando FL, Ponton J, Garaizar J, Rementeria A. 2010. What makes Aspergillus fumigatus a successful pathogen? Genes and molecules involved in invasive aspergillosis. Rev Iberoam Micol 27: 155-182.

Aimanianda V, Bayry J, Bozza S, Kniemeyer O, Perruccio K, Elluru SR, Clavaud C, Paris S, Brakhage AA, Kaveri SV, et al. 2009. Surface hydrophobin prevents immune recognition of airborne fungal spores. Nature 460: 11171121.

Alcazar-Fuoli L, Mellado E, Alastruey-Izquierdo A, CuencaEstrella M, Rodriguez-Tudela JL. 2008. Aspergillus section Fumigati: Antifungal susceptibility patterns and sequence-based identification. Antimicrob Agents Chemother 52: 1244-1251.

Alekseeva L, Huet D, Femenia F, Mouyna I, Abdelouahab M, Cagna A, Guerrier D, Tichanne-Seltzer V, Baeza-Squiban A, Chermette R, et al. 2009. Inducible expression of $\beta$ defensins by human respiratory epithelial cells exposed to Aspergillus fumigatus organisms. BMC Microbiol 9: 33.

Alhambra A, Catalan M, Moragues MD, Brena S, Ponton J, Montejo JC, del Palacio A. 2008. Isolation of Aspergillus lentulus in Spain from a critically ill patient with chronic obstructive pulmonary disease. Rev Iberoam Micol 25: 246-249.

Askew DS. 2008. Aspergillus fumigatus: Virulence genes in a street-smart mold. Curr Opin Microbiol 11: 331-337.

Baddley JW, Andes DR, Marr KA, Kontoyiannis DP, Alexander BD, Kauffman CA, Oster RA, Anaissie EJ, Walsh TJ Schuster MG, et al. 2010. Factors associated with mortality in transplant patients with invasive aspergillosis. Clin Infect Dis 50: 1559-1567.

Balajee SA, Nickle D, Varga J, Marr KA. 2006. Molecular studies reveal frequent misidentification of Aspergillus fumigatus by morphotyping. Eukaryot Cell 5: 1705-1712.

Barrs VR, van Doorn TM, Houbraken J, Kidd SE, Martin P, Pinheiro MD, Richardson M, Varga J, Samson RA. 2013. Aspergillus felis sp. nov., an emerging agent of invasive aspergillosis in humans, cats, and dogs. PLoS ONE 8: e64871.

Bayry J, Aimanianda V, Guijarro JI, Sunde M, Latgé JP. 2012. Hydrophobins_-Unique fungal proteins. PLoS Pathog 8: e1002700. 
Bhabhra R, Miley MD, Mylonakis E, Boettner D, Fortwendel J, Panepinto JC, Postow M, Rhodes JC, Askew DS. 2004. Disruption of the Aspergillus fumigatus gene encoding nucleolar protein CgrA impairs thermotolerant growth and reduces virulence. Infect Immun 72: 4731-4740.

Bok JW, Balajee SA, Marr KA, Andes D, Nielsen KF, Frisvad JC, Keller NP. 2005. LaeA, a regulator of morphogenetic fungal virulence factors. Eukaryot Cell 4: 1574-1582.

Brown GD, Denning DW, Gow NA, Levitz SM, Netea MG, White TC. 2012. Hidden killers: Human fungal infections. Sci Transl Med 4: 165rv113.

Bruns S, Kniemeyer O, Hasenberg M, Aimanianda V, Nietzsche S, Thywissen A, Jeron A, Latgé JP, Brakhage AA, Gunzer M. 2010. Production of extracellular traps against Aspergillus fumigatus in vitro and in infected lung tissue is dependent on invading neutrophils and influenced by hydrophobin RodA. PLoS Pathog 6: e1000873.

Caputo R. 2003. Itraconazole (Sporanox) in superficial and systemic fungal infections. Expert Rev Anti Infect Ther 1: 531-542.

Cohen MS, Isturiz RE, Malech HL, Root RK, Wilfert CM, Gutman L, Buckley RH. 1981. Fungal infection in chronic granulomatous disease. The importance of the phagocyte in defense against fungi. Am J Med 71: 59-66.

Cohen J, Postma DS, Douma WR, Vonk JM, De Boer AH, ten Hacken NH. 2011. Particle size matters: Diagnostics and treatment of small airways involvement in asthma. Eur Respir J 37: 532-540.

Conway SP, Etherington C, Peckham DG, Brownlee KG, Whitehead A, Cunliffe H. 2004. Pharmacokinetics and safety of itraconazole in patients with cystic fibrosis. $J$ Antimicrob Chemother 53: 841-847.

Coriglione G, Stella G, Gafa L, Spata G, Oliveri S, Padhye AA, Ajello L. 1990. Neosartorya fischeri var fischeri (Wehmer) Malloch and Cain 1972 (Anamorph: Aspergillus fischerianus Samson and Gams 1985) as a cause of mycotic keratitis. Eur J Epidemiol 6: 382-385.

Cramer RA Jr, Gamcsik MP, Brooking RM, Najvar LK, Kirkpatrick WR, Patterson TF, Balibar CJ, Graybill JR, Perfect JR, Abraham SN, et al. 2006. Disruption of a nonribosomal peptide synthetase in Aspergillus fumigatus eliminates gliotoxin production. Eukaryot Cell 5: 972-980.

Cramer RA Jr, Perfect BZ, Pinchai N, Park S, Perlin DS, Asfaw YG, Heitman J, Perfect JR, Steinbach WJ. 2008. Calcineurin target CrzA regulates conidial germination, hyphal growth, and pathogenesis of Aspergillus fumigatus. Eukaryot Cell 7: 1085-1097.

Dagenais TR, Keller NP. 2009. Pathogenesis of Aspergillus fumigatus in invasive aspergillosis. Clin Microbiol Rev 22: $447-465$.

da Silva Ferreira ME, Heinekamp T, Hartl A, Brakhage AA, Semighini CP, Harris SD, Savoldi M, de Gouvea PF, de Souza Goldman MH, Goldman GH. 2007. Functional characterization of the Aspergillus fumigatus calcineurin. Fungal Genet Biol 44: 219-230.

Denning DW. 1998. Invasive aspergillosis. Clin Infect Dis 26: $781-803$.

Denning DW, Evans EG, Kibbler CC, Richardson MD, Roberts MM, Rogers TR, Warnock DW, Warren RE. 1997. Guidelines for the investigation of invasive fungal infections in haematological malignancy and solid organ transplantation. Eur J Clin Microbiol Infect Dis 16: 424436.

Dinamarco TM, Almeida RS, de Castro PA, Brown NA, dos Reis TF, Ramalho LN, Savoldi M, Goldman MH, Goldman GH. 2012. Molecular characterization of the putative transcription factor SebA involved in virulence in Aspergillus fumigatus. Eukaryot Cell 11: 518-531.

Ejzykowicz DE, Cunha MM, Rozental S, Solis NV, Gravelat FN, Sheppard DC, Filler SG. 2009. The Aspergillus fumigatus transcription factor Ace2 governs pigment production, conidiation and virulence. Mol Microbiol 72: 155 169.

Ejzykowicz DE, Solis NV, Gravelat FN, Chabot J, Li X, Sheppard DC, Filler SG. 2010. Role of Aspergillus fumigatus DvrA in host cell interactions and virulence. Eukaryot Cell 9: 1432-1440.

Espinel-Ingroff A, Diekema DJ, Fothergill A, Johnson E, Pelaez T, Pfaller MA, Rinaldi MG, Canton E, Turnidge J. 2010. Wild-type MIC distributions and epidemiological cutoff values for the triazoles and six Aspergillus spp. for the CLSI broth microdilution method (M38-A2 document). J Clin Microbiol 48: 3251-3257.

Espinel-Ingroff A, Cuenca-Estrella M, Fothergill A, Fuller J, Ghannoum M, Johnson E, Pelaez T, Pfaller MA, Turnidge J. 2011. Wild-type MIC distributions and epidemiological cutoff values for amphotericin B and Aspergillus spp. for the CLSI broth microdilution method (M38-A2 document). Antimicrob Agents Chemother 55: 51505154.

Feng X, Krishnan K, Richie DL, Aimanianda V, Hartl L, Grahl N, Powers-Fletcher MV, Zhang M, Fuller KK, Nierman WC, et al. 2011. HacA-independent functions of the ER stress sensor IreA synergize with the canonical UPR to influence virulence traits in Aspergillus fumigatus. PLoS Pathog 7: e1002330.

Fortwendel JR, Zhao W, Bhabhra R, Park S, Perlin DS, Askew DS, Rhodes JC. 2005. A fungus-specific Ras homolog contributes to the hyphal growth and virulence of Aspergillus fumigatus. Eukaryot Cell 4: 1982-1989.

Fortwendel JR, Juvvadi PR, Rogg LE, Asfaw YG, Burns KA, Randell SH, Steinbach WJ. 2012. Plasma membrane localization is required for RasA-mediated polarized morphogenesis and virulence of Aspergillus fumigatus. Eukaryot Cell 11: 966-977.

Fresenius G. 1863. Beiträge zur Mykologie. H.L. Bronner, Frankfurt.

Gams W, Christensen M, Onions AH, Pitt JI, Samson RA. 1985. Infrageneric taxa of Aspergillus. In Advances in penicillium and Aspergillus systematics (ed. Samson RA, Pitt J), pp. 55-62. Plenum, New York.

Ghebremedhin B, Bluemel A, Neumann KH, Koenig B, Koenig W. 2009. Peritonitis due to Neosartorya pseudofischeri in an elderly patient undergoing peritoneal dialysis successfully treated with voriconazole. J Med Microbiol 58: $678-682$.

Girmenia C, Nucci M, Martino P. 2001. Clinical significance of Aspergillus fungaemia in patients with haematological malignancies and invasive aspergillosis. $\mathrm{Br} \mathrm{J}$ Haematol 114: 93-98.

Grahl N, Dinamarco TM, Willger SD, Goldman GH, Cramer RA. 2012. Aspergillus fumigatus mitochondrial electron transport chain mediates oxidative stress ho- 
J.A. Sugui et al.

meostasis, hypoxia responses and fungal pathogenesis. Mol Microbiol 84: 383-399.

Gravelat FN, Ejzykowicz DE, Chiang LY, Chabot JC, Urb M, Macdonald KD, al-Bader N, Filler SG, Sheppard DC. 2010. Aspergillus fumigatus MedA governs adherence, host cell interactions and virulence. Cell Microbiol 12: 473-488.

Groll AH, Shah PM, Mentzel C, Schneider M, Just-Nuebling G, Huebner K. 1996. Trends in the postmortem epidemiology of invasive fungal infections at a university hospital. J Infect 33: 23-32.

Guarro J, Kallas EG, Godoy P, Karenina A, Gene J, Stchigel A, Colombo AL. 2002. Cerebral aspergillosis caused by Neosartorya hiratsukae, Brazil. Emerg Infect Dis 8: 989-991.

Gyotoku H, Izumikawa K, Ikeda H, Takazono T, Morinaga Y, Nakamura S, Imamura Y, Nishino T, Miyazaki T, Kakeya $\mathrm{H}$, et al. 2012. A case of bronchial aspergillosis caused by Aspergillus udagawae and its mycological features. Med Mycol 50: 631-636.

Haas H. 2012. Iron-A key nexus in the virulence of Aspergillus fumigatus. Front Microbiol 3: 28.

Hawksworth DL, Crous PW, Redhead SA, Reynolds DR, Samson RA, Seifert KA, Taylor JW, Wingfield MJ, Abaci O, Aime C, et al. 2011. The Amsterdam declaration on fungal nomenclature. IMA Fungus 2: 105-112.

Heinekamp T, Thywissen A, Macheleidt J, Keller S, Valiante V, Brakhage AA. 2013. Aspergillus fumigatus melanins: Interference with the host endocytosis pathway and impact on virulence. Front Microbiol 3: 440.

Henriet S, Verweij PE, Holland SM, Warris A. 2013. Invasive fungal infections in patients with chronic granulomatous disease. Adv Exp Med Biol 764: 27-55.

Hensel M, Arst HN Jr, Aufauvre-Brown A, Holden DW. 1998. The role of the Aspergillus fumigatus areA gene in invasive pulmonary aspergillosis. Mol Gen Genet 258: 553-557.

Herbrecht R, Denning DW, Patterson TF, Bennett JE, Greene RE, Oestmann JW, Kern WV, Marr KA, Ribaud P, Lortholary O, et al. 2002. Voriconazole versus amphotericin B for primary therapy of invasive aspergillosis. $N$ Engl $J$ Med 347: 408-415.

Hissen AH, Wan AN, Warwas ML, Pinto LJ, Moore MM. 2005. The Aspergillus fumigatus siderophore biosynthetic gene sidA, encoding L-ornithine N5-oxygenase, is required for virulence. Infect Immun 73: 5493-5503.

Ho PL, Yuen KY. 2000. Aspergillosis in bone marrow transplant recipients. Crit Rev Oncol Hematol 34: 55-69.

Hohl TM, Feldmesser M. 2007. Aspergillus fumigatus: Principles of pathogenesis and host defense. Eukaryot Cell 6: 1953-1963.

Horn BW, Moore GG, Carbone I. 2009. Sexual reproduction in Aspergillus flavus. Mycologia 101: 423-429.

Houbraken J, Samson RA. 2011. Phylogeny of Penicillium and the segregation of Trichocomaceae into three families. Stud Mycol 70: 1-51.

Ibrahim-Granet O, Philippe B, Boleti H, Boisvieux-Ulrich E, Grenet D, Stern M, Latgé JP. 2003. Phagocytosis and intracellular fate of Aspergillus fumigatus conidia in alveolar macrophages. Infect Immun 71: 891-903.

Ibrahim-Granet O, Dubourdeau M, Latgé JP, Ave P, Huerre M, Brakhage AA, Brock M. 2008. Methylcitrate synthase from Aspergillus fumigatus is essential for manifestation of invasive aspergillosis. Cell Microbiol 10: 134-148.

Jantunen E, Ruutu P, Piilonen A, Volin L, Parkkali T, Ruutu T. 2000. Treatment and outcome of invasive Aspergillus infections in allogeneic BMT recipients. Bone Marrow Transplant 26: 759-762.

Jarv H, Lehtmaa J, Summerbell RC, Hoekstra ES, Samson RA, Naaber P. 2004. Isolation of Neosartorya pseudofischeri from blood: First hint of pulmonary aspergillosis. J Clin Microbiol 42: 925-928.

Jensen HL. 1931. The fungus flora of the soil. Soil Sci 31: $123-158$.

Kawazu M, Kanda Y, Nannya Y, Aoki K, Kurokawa M, Chiba S, Motokura T, Hirai H, Ogawa S. 2004. Prospective comparison of the diagnostic potential of real-time PCR, double-sandwich enzyme-linked immunosorbent assay for galactomannan, and a $(1 \rightarrow 3)-\beta$-D-glucan test in weekly screening for invasive aspergillosis in patients with hematological disorders. J Clin Microbiol 42: 2733-2741.

Kontoyiannis DP, Bodey GP. 2002. Invasive aspergillosis in 2002: An update. Eur J Clin Microbiol Infect Dis 21: 161 172.

Kozakiewicz Z, Smith D. 1994. Physiology of Aspergillus. In Biotechnology handbooks: Aspergillus (ed. Smith JE), pp. 23-38. Plenum, New York.

Krappmann S, Bignell EM, Reichard U, Rogers T, Haynes K, Braus GH. 2004. The Aspergillus fumigatus transcriptional activator CpcA contributes significantly to the virulence of this fungal pathogen. Mol Microbiol 52: 785-799.

Kupfahl C, Heinekamp T, Geginat G, Ruppert T, Hartl A, Hof H, Brakhage AA. 2006. Deletion of the gliP gene of Aspergillus fumigatus results in loss of gliotoxin production but has no effect on virulence of the fungus in a lowdose mouse infection model. Mol Microbiol 62: 292-302.

Kwon-Chung KJ, Bennett JE. 1992. Medical mycology. Lea \& Febiger, Philadelphia.

Kwon-Chung J, Sugui JA. 2013. Aspergillus fumigatusWhat makes the species a ubiquitous human fungal pathogen? PLoS Pathog 9: e1003743.

Lamoth F, Cruciani M, Mengoli C, Castagnola E, Lortholary O, Richardson M, Marchetti O. 2012. $\beta$-Glucan antigenemia assay for the diagnosis of invasive fungal infections in patients with hematological malignancies: A systematic review and meta-analysis of cohort studies from the Third European Conference on Infections in Leukemia (ECIL-3). Clin Infect Dis 54: 633-643.

Langfelder K, Jahn B, Gehringer H, Schmidt A, Wanner G, Brakhage AA. 1998. Identification of a polyketide synthase gene ( $p k s P)$ of Aspergillus fumigatus involved in conidial pigment biosynthesis and virulence. Med Microbiol Immunol 187: 79-89.

Latgé JP. 1999. Aspergillus fumigatus and aspergillosis. Clin Microbiol Rev 12: 310-350.

Lessing F, Kniemeyer O, Wozniok I, Loeffler J, Kurzai O, Haertl A, Brakhage AA. 2007. The Aspergillus fumigatus transcriptional regulator AfYapl represents the major regulator for defense against reactive oxygen intermediates but is dispensable for pathogenicity in an intranasal mouse infection model. Eukaryot Cell 6: 2290-2302. 
Li H, Zhou H, Luo Y, Ouyang H, Hu H, Jin C. 2007. Glycosylphosphatidylinositol (GPI) anchor is required in Aspergillus fumigatus for morphogenesis and virulence. Mol Microbiol 64: 1014-1027.

Liebmann B, Muller M, Braun A, Brakhage AA. 2004. The cyclic AMP-dependent protein kinase a network regulates development and virulence in Aspergillus fumigatus. Infect Immun 72: 5193-5203.

Lin SJ, Schranz J, Teutsch SM. 2001. Aspergillosis case-fatality rate: Systematic review of the literature. Clin Infect Dis 32: $358-366$.

Liu H, Gravelat FN, Chiang LY, Chen D, Vanier G, Ejzykowicz DE, Ibrahim AS, Nierman WC, Sheppard DC, Filler SG. 2010. Aspergillus fumigatus AcuM regulates both iron acquisition and gluconeogenesis. Mol Microbiol 78: $1038-1054$.

Lonial S, Williams L, Carrum G, Ostrowski M, McCarthy P Jr 1997. Neosartorya fischeri: An invasive fungal pathogen in an allogeneic bone marrow transplant patient. Bone Marrow Transplant 19: 753-755.

Lortholary O, Gangneux JP, Sitbon K, Lebeau B, de Monbrison F, Le Strat Y, Coignard B, Dromer F, Bretagne S. 2011. Epidemiological trends in invasive aspergillosis in France: The SAIF network (2005-2007). Clin Microbiol Infect 17: 1882-1889.

Ma YJ, Doni A, Romani L, Jurgensen HJ, Behrendt N, Mantovani A, Garred P. 2013. Ficolin-1-PTX3 complex formation promotes clearance of altered self-cells and modulates IL-8 production. J Immunol 191: 1324-1333.

Madan T, Reid KB, Clark H, Singh M, Nayak A, Sarma PU, Hawgood S, Kishore U. 2010. Susceptibility of mice genetically deficient in SP-A or SP-D gene to invasive pulmonary aspergillosis. Mol Immunol 47: 1923-1930.

Maertens J, Verhaegen J, Demuynck H, Brock P, Verhoef G, Vandenberghe P, Van Eldere J, Verbist L, Boogaerts M. 1999. Autopsy-controlled prospective evaluation of serial screening for circulating galactomannan by a sandwich enzyme-linked immunosorbent assay for hematological patients at risk for invasive aspergillosis. J Clin Microbiol 37: 3223-3228.

Malejczyk K, Sigler L, Gibas CF, Smith SW. 2013. Invasive sino-orbital mycosis in an aplastic anemia patient caused by Neosartorya laciniosa. J Clin Microbiol 51: 1316-1319.

Marr KA, Carter RA, Crippa F, Wald A, Corey L. 2002a. Epidemiology and outcome of mould infections in hematopoietic stem cell transplant recipients. Clin Infect Dis 34: 909-917.

Marr KA, Patterson T, Denning D. 2002b. Aspergillosis. Pathogenesis, clinical manifestations, and therapy. Infect Dis Clin North Am 16: 875-894.

Marr KA, Balajee SA, McLaughlin L, Tabouret M, Bentsen C, Walsh TJ. 2004. Detection of galactomannan antigenemia by enzyme immunoassay for the diagnosis of invasive aspergillosis: Variables that affect performance. $J$ Infect Dis 190: 641-649.

Maubon D, Park S, Tanguy M, Huerre M, Schmitt C, Prevost MC, Perlin DS, Latgé JP, Beauvais A. 2006. AGS3, an $\alpha(1-3)$ glucan synthase gene family member of Aspergillus fumigatus, modulates mycelium growth in the lung of experimentally infected mice. Fungal Genet Biol 43: 366375.
McCormick A, Heesemann L, Wagener J, Marcos V, Hartl D, Loeffler J, Heesemann J, Ebel F. 2010. NETs formed by human neutrophils inhibit growth of the pathogenic mold Aspergillus fumigatus. Microbes Infect 12: 928-936.

McDonagh A, Fedorova ND, Crabtree J, Yu Y, Kim S, Chen D, Loss O, Cairns T, Goldman G, Armstrong-James D, et al. 2008. Sub-telomere directed gene expression during initiation of invasive aspergillosis. PLoS Pathog 4: e1000154.

Mellado E, Aufauvre-Brown A, Gow NA, Holden DW. 1996. The Aspergillus fumigatus chs $C$ and $\operatorname{chs} G$ genes encode class III chitin synthases with different functions. Mol Microbiol 20: 667-679.

Montenegro G, Sanchez Puch S, Jewtuchowicz VM, Pinoni MV, Relloso S, Temporitti E, Iovannitti CA, Mujica MT 2009. Phenotypic and genotypic characterization of Aspergillus lentulus and Aspergillus fumigatus isolates in a patient with probable invasive aspergillosis. J Med Microbiol 58: 391-395.

Moore MM. 2013. The crucial role of iron uptake in Aspergillus fumigatus virulence. Curr Opin Microbiol 16: 692 699.

Moreno MA, Ibrahim-Granet O, Vicentefranqueira R, Amich J, Ave P, Leal F, Latgé JP, Calera JA. 2007. The regulation of zinc homeostasis by the ZafA transcriptional activator is essential for Aspergillus fumigatus virulence. Mol Microbiol 64: 1182-1197.

Mouyna I, Morelle W, Vai M, Monod M, Lechenne B, Fontaine T, Beauvais A, Sarfati J, Prevost MC, Henry C, et al. 2005. Deletion of GEL2 encoding for a $\beta$ (1-3) glucanosyltransferase affects morphogenesis and virulence in Aspergillus fumigatus. Mol Microbiol 56: 1675-1688.

Obayashi T, Yoshida M, Mori T, Goto H, Yasuoka A, Iwasaki H, Teshima H, Kohno S, Horiuchi A, Ito A, et al. 1995. Plasma $(1 \rightarrow 3)-\beta$-D-glucan measurement in diagnosis of invasive deep mycosis and fungal febrile episodes. Lancet 345: $17-20$.

O'Gorman CM, Fuller HT, Dyer PS. 2009. Discovery of a sexual cycle in the opportunistic fungal pathogen Aspergillus fumigatus. Nature 457: 471-474.

Okamoto T, Tanida T, Wei B, Ueta E, Yamamoto T, Osaki T. 2004. Regulation of fungal infection by a combination of amphotericin B and peptide 2, a lactoferrin peptide that activates neutrophils. Clin Diagn Lab Immunol 11: 11111119.

Padhye AA, Godfrey JH, Chandler FW, Peterson SW. 1994 Osteomyelitis caused by Neosartorya pseudofischeri. J Clin Microbiol 32: 2832-2836.

Pagano L, Caira M, Candoni A, Offidani M, Martino B, Specchia G, Pastore D, Stanzani M, Cattaneo C, Fanci $\mathrm{R}$, et al. 2010. Invasive aspergillosis in patients with acute myeloid leukemia: A SEIFEM-2008 registry study. Haematologica 95: 644-650.

Panepinto JC, Oliver BG, Fortwendel JR, Smith DL, Askew DS, Rhodes JC. 2003. Deletion of the Aspergillus fumigatus gene encoding the Ras-related protein RhbA reduces virulence in a model of invasive pulmonary aspergillosis. Infect Immun 71: 2819-2826.

Pappas PG, Alexander BD, Andes DR, Hadley S, Kauffman CA, Freifeld A, Anaissie EJ, Brumble LM, Herwaldt L, Ito $\mathrm{J}$, et al. 2010. Invasive fungal infections among organ transplant recipients: Results of the Transplant-Associat- 
J.A. Sugui et al.

ed Infection Surveillance Network (TRANSNET). Clin Infect Dis 50: 1101-1111.

Paris S, Wysong D, Debeaupuis JP, Shibuya K, Philippe B, Diamond RD, Latgé JP. 2003. Catalases of Aspergillus fumigatus. Infect Immun 71: 3551-3562.

Pelaez T, Alvarez-Perez S, Mellado E, Serrano D, Valerio M, Blanco JL, Garcia ME, Munoz P, Cuenca-Estrella M, Bouza E. 2013. Invasive aspergillosis caused by cryptic Aspergillus species: A report of two consecutive episodes in a patient with leukaemia. J Med Microbiol 62: 474478.

Perfect JR, Cox GM, Lee JY, Kauffman CA, de Repentigny L, Chapman SW, Morrison VA, Pappas P, Hiemenz JW, Stevens DA, Mycoses Study Group. 2001. The impact of culture isolation of Aspergillus species: A hospital-based survey of aspergillosis. Clin Infect Dis 33: 1824-1833.

Peterson SW. 2008. Phylogenetic analysis of Aspergillus species using DNA sequences from four loci. Mycologia 100: 205-226.

Pfeiffer CD, Fine JP, Safdar N. 2006. Diagnosis of invasive aspergillosis using a galactomannan assay: A meta-analysis. Clin Infect Dis 42: 1417-1427.

Posteraro B, Mattei R, Trivella F, Maffei A, Torre A, De Carolis E, Posteraro P, Fadda G, Sanguinetti M. 2011. Uncommon Neosartorya udagawae fungus as a causative agent of severe corneal infection. J Clin Microbiol 49: 2357-2360.

Rankin NE. 1953. Disseminated aspergillosis and moniliasis associated with agranulocytosis and antibiotic therapy. Brit Med J 183: 918-919.

Raper KB, Fennell DI. 1965. The genus Aspergillus. Williams \& Wilkins, Baltimore.

Reeves EP, Reiber K, Neville C, Scheibner O, Kavanagh K, Doyle S. 2006. A nonribosomal peptide synthetase (Pes1) confers protection against oxidative stress in Aspergillus fumigatus. FEBS J 273: 3038-3053.

Richardson MD. 2005. Changing patterns and trends in systemic fungal infections. J Antimicrob Chemother 56: i5-i11.

Romano J, Nimrod G, Ben-Tal N, Shadkchan Y, Baruch K, Sharon H, Osherov N. 2006. Disruption of the Aspergillus fumigatus ECM33 homologue results in rapid conidial germination, antifungal resistance and hypervirulence. Microbiology 152: 1919-1928.

Sales-Campos H, Tonani L, Cardoso CR, Kress MR. 2013. The immune interplay between the host and the pathogen in Aspergillus fumigatus lung infection. Biomed Res Int 2013: 693023.

Samson RA, Hong S, Peterson SW, Frisvad JC, Varga J. 2007. Polyphasic taxonomy of Aspergillus section Fumigati and its teleomorph Neosartorya. Stud Mycol 59: 147-203.

Saugier-Veber P, Devergie A, Sulahian A, Ribaud P, Traore F, Bourdeau-Esperou H, Gluckman E, Derouin F. 1993. Epidemiology and diagnosis of invasive pulmonary aspergillosis in bone marrow transplant patients: Results of a 5 year retrospective study. Bone Marrow Transplant 12: 121-124.

Schell WA. 1995. New aspects of emerging fungal pathogens. A multifaceted challenge. Clin Lab Med 15: 365-387.

Schmalhorst PS, Krappmann S, Vervecken W, Rohde M, Muller M, Braus GH, Contreras R, Braun A, Bakker H,
Routier FH. 2008. Contribution of galactofuranose to the virulence of the opportunistic pathogen Aspergillus fumigatus. Eukaryot Cell 7: 1268-1277.

Schmitt I, Crespo A, Divakar PK, Fankhauser JD, HermanSackett E, Kalb K, Nelsen MP, Nelson NA, Rivas-Plata E, Shimp AD, et al. 2009. New primers for promising singlecopy genes in fungal phylogenetics and systematics. Persoonia 23: $35-40$.

Schrettl M, Bignell E, Kragl C, Joechl C, Rogers T, Arst HN Jr, Haynes K, Haas H. 2004. Siderophore biosynthesis but not reductive iron assimilation is essential for Aspergillus fumigatus virulence. J Exp Med 200: 1213-1219.

Schrettl M, Bignell E, Kragl C, Sabiha Y, Loss O, Eisendle M, Wallner A, Arst HN Jr, Haynes K, Haas H. 2007. Distinct roles for intra- and extracellular siderophores during Aspergillus fumigatus infection. PLoS Pathog 3: e128.

Segal BH, DeCarlo ES, Kwon-Chung KJ, Malech HL, Gallin JI, Holland SM. 1998. Aspergillus nidulans infection in chronic granulomatous disease. Medicine (Baltimore) 77: 345-354.

Shivaprakash MR, Jain N, Gupta S, Baghela A, Gupta A, Chakrabarti A. 2009. Allergic fungal rhinosinusitis caused by Neosartorya hiratsukae from India. Med Mycol 47: $317-320$.

Singh PK, Kathuria S, Agarwal K, Gaur SN, Meis JF, Chowdhary A. 2013. Clinical significance and molecular characterization of non-sporulating moulds isolated from the respiratory tract of bronchopulmonary mycoses patients with special reference to basidiomycetes. J Clin Microbiol 51: 3331-3337.

Soriani FM, Malavazi I, da Silva Ferreira ME, Savoldi M, Von Zeska Kress MR, de Souza Goldman MH, Loss O, Bignell E, Goldman GH. 2008. Functional characterization of the Aspergillus fumigatus CRZ1 homologue, CrzA. Mol Microbiol 67: 1274-1291.

Spikes S, Xu R, Nguyen CK, Chamilos G, Kontoyiannis DP, Jacobson RH, Ejzykowicz DE, Chiang LY, Filler SG, May GS. 2008. Gliotoxin production in Aspergillus fumigatus contributes to host-specific differences in virulence. J Infect Dis 197: 479-486.

Steinbach WJ, Cramer RA Jr, Perfect BZ, Asfaw YG, Sauer TC, Najvar LK, Kirkpatrick WR, Patterson TF, Benjamin DK Jr, Heitman J, et al. 2006. Calcineurin controls growth, morphology, and pathogenicity in Aspergillus fumigatus. Eukaryot Cell 5: 1091-1103.

Steinbach WJ, Reedy JL, Cramer RA Jr, Perfect JR, Heitman J. 2007. Harnessing calcineurin as a novel anti-infective agent against invasive fungal infections. Nat Rev Microbiol 5: 418-430.

Stevens DA, Schwartz HJ, Lee JY, Moskovitz BL, Jerome DC, Catanzaro A, Bamberger DM, Weinmann AJ, Tuazon CU, Judson MA, et al. 2000. A randomized trial of itraconazole in allergic bronchopulmonary aspergillosis. $N \mathrm{Engl} \mathrm{J}$ Med 342: 756-762.

Stevens DA, Moss RB, Kurup VP, Knutsen AP, Greenberger P, Judson MA, Denning DW, Crameri R, Brody AS, Light $\mathrm{M}$, et al. 2003. Allergic bronchopulmonary aspergillosis in cystic fibrosis-State of the art: Cystic Fibrosis Foundation Consensus Conference. Clin Infect Dis 37: S225S264.

Stynen D, Goris A, Sarfati J, Latgé JP. 1995. A new sensitive sandwich enzyme-linked immunosorbent assay to detect 
galactofuran in patients with invasive aspergillosis. J Clin Microbiol 33: 497-500.

Sugui JA, Pardo J, Chang YC, Zarember KA, Nardone G, Galvez EM, Mullbacher A, Gallin JI, Simon MM, Kwon-Chung KJ. 2007. Gliotoxin is a virulence factor of Aspergillus fumigatus: gliP deletion attenuates virulence in mice immunosuppressed with hydrocortisone. Eukaryot Cell 6: 1562-1569.

Sugui JA, Vinh DC, Nardone G, Shea YR, Chang YC, Zelazny AM, Marr KA, Holland SM, Kwon-Chung KJ. 2010. Neosartorya udagawae (Aspergillus udagawae), an emerging agent of aspergillosis: How different is it from Aspergillus fumigatus? J Clin Microbiol 48: 220-228.

Summerbell RC, de Repentigny L, Chartrand C, St Germain G. 1992. Graft-related endocarditis caused by Neosartorya fischeri var. spinosa. J Clin Microbiol 30: 1580-1582.

Svirshchevskaya E, Zubkov D, Mouyna I, Berkova N. 2012. Innate immunity and the role of epithelial barrier during Aspergillus fumigatus infection. Curr Immunol Rev 8: 254-261.

Swilaiman SS, O'Gorman CM, Balajee SA, Dyer PS. 2013. Discovery of a sexual cycle in Aspergillus lentulus, a close relative of A. fumigatus. Eukaryot Cell 12: 962-969.

Symoens F, Haase G, Pihet M, Carrere J, Beguin H, Degand N, Mely L, Bouchara JP. 2010. Unusual Aspergillus species in patients with cystic fibrosis. Med Mycol 48: S10-S16.

Tekaia F, Latgé JP. 2005. Aspergillus fumigatus: Saprophyte or pathogen? Curr Opin Microbiol 8: 385-392.

Thom C, Church MB. 1918. Aspergillus fumigatus, A. nidulans, A. terreus N. Sp. and their allies. Am J Bot 5: 84-104.

Thom C, Church MB. 1926. The Aspergili. Williams \& Wilkins, Baltimore.

Tomee JF, van der Werf TS. 2001. Pulmonary aspergillosis. Neth J Med 59: 244-258.

Toskova M, Palousova D, Kocmanova I, Pavlovsky Z, Timilsina S, Lengerova M, Mayer J, Racil Z. 2013. Invasive mould disease involving the gastrointestinal tract caused by Neosartorya pseudofischeri in a haematological patient. Mycoses 56: 385-388.

Tsai HF, Chang YC, Washburn RG, Wheeler MH, KwonChung KJ. 1998. The developmentally regulated alb1 gene of Aspergillus fumigatus: Its role in modulation of conidial morphology and virulence. J Bacteriol 180: 3031-3038.

Tsitsigiannis DI, Bok JW, Andes D, Nielsen KF, Frisvad JC, Keller NP. 2005. Aspergillus cyclooxygenase-like enzymes are associated with prostaglandin production and virulence. Infect Immun 73: 4548-4559.

Urban CF, Reichard U, Brinkmann V, Zychlinsky A. 2006. Neutrophil extracellular traps capture and kill Candida albicans yeast and hyphal forms. Cell Microbiol 8: 668676.

Vinh DC, Shea YR, Jones PA, Freeman AF, Zelazny A, Holland SM. 2009a. Chronic invasive aspergillosis caused by Aspergillus viridinutans. Emerg Infect Dis 15: 1292-1294.

Vinh DC, Shea YR, Sugui JA, Parrilla-Castellar ER, Freeman AF, Campbell JW, Pittaluga S, Jones PA, Zelazny A, Kleiner D, et al. 2009b. Invasive aspergillosis due to Neosartorya udagawae. Clin Infect Dis 49: 102-111.

Virchow R. 1856. Beitrage zur Lehere von den beim Menschen vorkommenden pflanzlichen Parasiten. Arch Pathol Anat Physiol Klin Med 9: 557-593.

Wagener J, Echtenacher B, Rohde M, Kotz A, Krappmann S, Heesemann J, Ebel F. 2008. The putative $\alpha$-1,2-mannosyltransferase AfMntl of the opportunistic fungal pathogen Aspergillus fumigatus is required for cell wall stability and full virulence. Eukaryot Cell 7: 1661-1673.

Wald A, Leisenring W, van Burik JA, Bowden RA. 1997. Epidemiology of Aspergillus infections in a large cohort of patients undergoing bone marrow transplantation. $J$ Infect Dis 175: 1459-1466.

Walsh TJ, Anaissie EJ, Denning DW, Herbrecht R, Kontoyiannis DP, Marr KA, Morrison VA, Segal BH, Steinbach WJ, Stevens DA, et al. 2008. Treatment of aspergillosis: Clinical practice guidelines of the Infectious Diseases Society of America. Clin Infect Dis 46: 327-360.

White TJ, Bruns T, Lee S, Taylor JW. 1990. Amplification and direct sequencing of fungal ribosomal RNA genes for phylogenetics. In PCR protocols: A guide to methods and applications (ed. Innis MA, Gelfand DH, Sninsky JJ, White TJ), pp. 315-322. Academic, New York.

Willger SD, Puttikamonkul S, Kim KH, Burritt JB, Grahl N, Metzler LJ, Barbuch R, Bard M, Lawrence CB, Cramer RA Jr 2008. A sterol-regulatory element binding protein is required for cell polarity, hypoxia adaptation, azole drug resistance, and virulence in Aspergillus fumigatus. PLoS Pathog 4: e1000200.

Yaguchi T, Horie Y, Tanaka R, Matsuzawa T, Ito J, Nishimura K. 2007. Molecular phylogenetics of multiple genes on Aspergillus section Fumigati isolated from clinical specimens in Japan. Nippon Ishinkin Gakkai Zasshi 48: 37-46.

Zbinden A, Imhof A, Wilhelm MJ, Ruschitzka F, Wild P, Bloemberg GV, Mueller NJ. 2012. Fatal outcome after heart transplantation caused by Aspergillus lentulus. Transpl Infect Dis 14: E60-E63.

Zhao W, Panepinto JC, Fortwendel JR, Fox L, Oliver BG, Askew DS, Rhodes JC. 2006. Deletion of the regulatory subunit of protein kinase A in Aspergillus fumigatus alters morphology, sensitivity to oxidative damage, and virulence. Infect Immun 74: 4865-4874. 


\section{$\&_{\mathrm{CSH}}^{\infty} \&$ Cold Spring Harbor

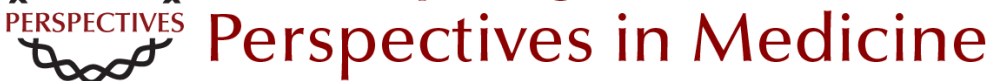

\section{Aspergillus fumigatus and Related Species}

Janyce A. Sugui, Kyung J. Kwon-Chung, Praveen R. Juvvadi, Jean-Paul Latgé and William J. Steinbach

Cold Spring Harb Perspect Med 2015; doi: 10.1101/cshperspect.a019786 originally published online November 6, 2014

Subject Collection Human Fungal Pathogens

\section{Evolutionary Perspectives on Human Fungal Pathogens John W. Taylor}

Black Molds and Melanized Yeasts Pathogenic to Humans Anuradha Chowdhary, John Perfect and G. Sybren de Hoog

Fungal Pathogens: Survival and Replication within Macrophages Andrew S. Gilbert, Robert T. Wheeler and Robin C. May

Innate Defense against Fungal Pathogens Rebecca A. Drummond, Sarah L. Gaffen, Amy G. Hise, et al.

Antifungal Pharmacokinetics and Pharmacodynamics Alexander J. Lepak and David R. Andes

Human Fungal Pathogens of Mucorales and Entomophthorales Leonel Mendoza, Raquel Vilela, Kerstin Voelz, et al.

Functional Profiling of Human Fungal Pathogen Genomes Alexi I. Goranov and Hiten D. Madhani

Aspergillus fumigatus and Related Species Janyce A. Sugui, Kyung J. Kwon-Chung, Praveen R. Juvvadi, et al.
Thermally Dimorphic Human Fungal Pathogens-Polyphyletic Pathogens with a Convergent

Pathogenicity Trait Anita Sil and Alex Andrianopoulos

Mechanisms of Antifungal Drug Resistance Leah E. Cowen, Dominique Sanglard, Susan J. Howard, et al.

Treatment Principles for Candida and Cryptococcus Laura C. Whitney and Tihana Bicanic

The Human Mycobiome Patrick C. Seed

Treatment Principles for the Management of Mold Infections

Dimitrios P. Kontoyiannis and Russell E. Lewis

Adaptive Immunity to Fungi Akash Verma, Marcel Wüthrich, George Deepe, et al.

The Candida Pathogenic Species Complex Siobhán A. Turner and Geraldine Butler

Fungal Morphogenesis Xiaorong Lin, J. Andrew Alspaugh, Haoping Liu, et al.

For additional articles in this collection, see http://perspectivesinmedicine.cshlp.org/cgi/collection/ 